\title{
OSTEOMYELITIS ON THE CERVICAL VERTEBRAS OF A FREE-LIVING EUROPEAN HEDGEHOG (Erinaceus europaeus) BY Paeniclostridium sordellii
}

\author{
Andreia Garcês ${ }^{1 *}$, Vanessa Soeiro², Sara Lóio², Filipe Silva ${ }^{3,4}$, Isabel Pires ${ }^{3,4}$ \\ 'Inno - Serviços Especializados em Veterinária, R. Cândido de Sousa 15, 4710-300 Braga, Portugal, Wildlife Rehabilitation Centre of Parque \\ Biológico de Gaia, Rua da Cunha, 152, Avintes, ${ }^{3}$ Veterinary Science Department, ${ }^{4}$ CECAV, University of Trás-OS-Montes and Alto Douro, \\ 5000-801, Vila Real, Portugal
}

${ }^{*}$ Corresponding author, E-mail: andreiamvg@gmail.com

\begin{abstract}
A free-living European hedgehog (Erinaceus europaeus) adult female was admitted to the Wildlife Rehabilitation Centre of Parque Biológico de Gaia (Portugal), with severe breathing distress and poor body condition. Its neck was displaced 60 degrees caudally. During the post- mortem exam, an abscess in the cervical vertebras was observed. Paeniclostridium sordellii was the agent isolated from the purulent exudate that was removed from the lesion. This is the first reported case of $P$. sordellii associated osteomyelitis on the cervical vertebras, and the first time that this pathology is describe in this specie associated with this agent.
\end{abstract}

Key words: Erinaceus europaeus; Portugal; Paeniclostridium sordellii; osteomyelitis

\section{Introduction}

The Western European hedgehog Erinaceus europaeus (Linnaeus, 1758) is a generalist mammal, widely distributed by the European continent (1-3). Highly adaptable animals that can be frequently observed in green spaces in constructed-up areas such as gardens and parks in the cities $(4,5)$. Hedgehogs are one of the most common species admitted to wildlife rehabilitation centres or veterinary hospital, but still little is known about their diseases and agents $(5,6)$.

Usually, cervical osteomyelitis occurs in very old individuals or young animals with active

Received: 13 May 2020

Accepted for publication: 17 December 2020 growth plates, associated with Staphylococci spp and Escherichia coli infection (7). In hedgehogs cases of maxillary osteomyelitis had already be reported (8).

Paenisclostridium sordellii (previously Clostridium sordellii) is a gram-positive, sporulating anaerobic rod that is a common inhabitant of soil, and very rarely can be found in the intestinal content of clinically healthy animals. It can invade wounds and tissues pre and post mortem. It has been be associated with enteric disease of several animal species, but still remains controversial (9-11) including several clostridial species. $P$. sordellii is also responsible for fatal toxic shock and bacteraemia in humans (10). 
An adult female of European hedgehog ( $E$. europaeus) weighing $560 \mathrm{~g}$ was admitted to the Wildlife Rehabilitation Centre of Parque Biologico de Gaia (Portugal), after being found during the day in a suburban area, with prostration and respiratory difficulties. On examination, the

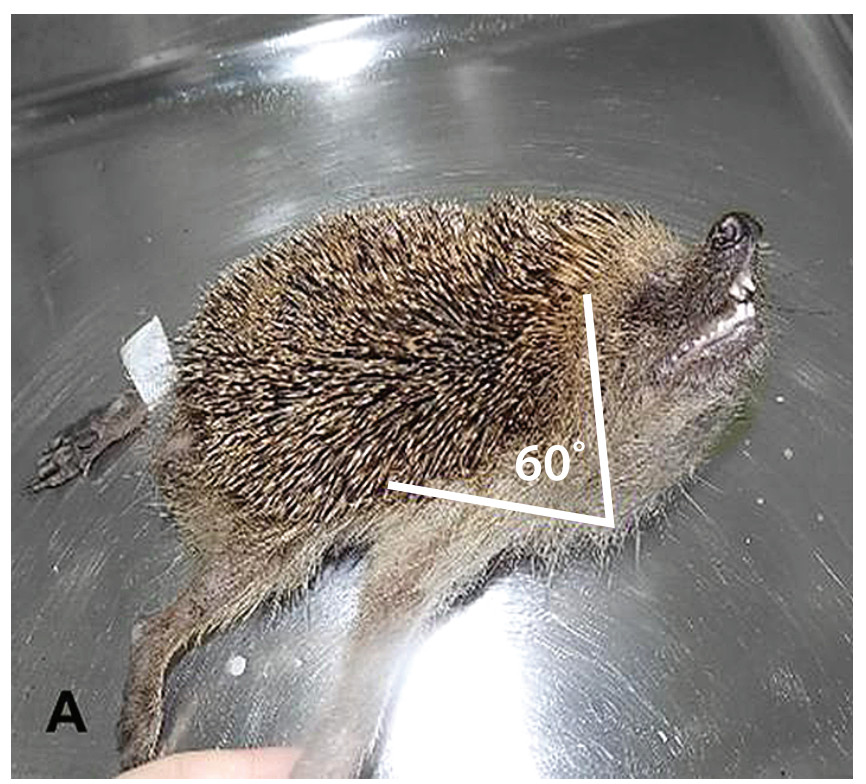

animal had a poor body condition, weakness of the limbs, pallid mucosa's, respiratory distress, an abnormal position of the neck and dehydration. Its neck was displaced 60 degrees caudally, as observed in Figure 1A. Unfortunately, the animal died during the treatment.

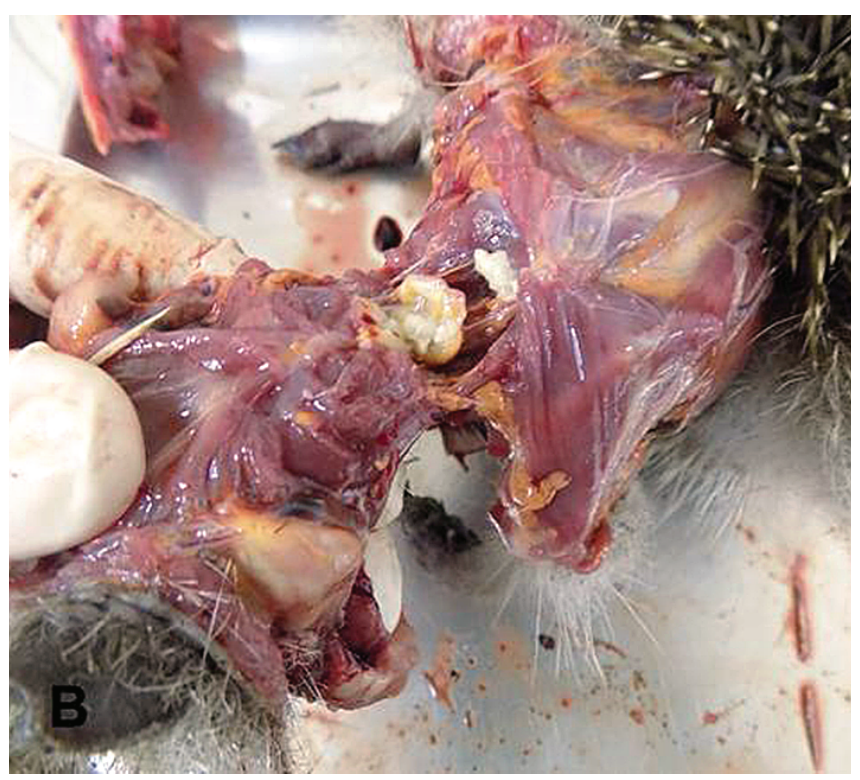

Figure 1: A Erinaceus europaeus with the neck pushed in 60 degrees caudally. In B encapsulated nodule with $1 \mathrm{~cm}$ in diameter, filled with a whitish purulent exudate, on the C2-C3 vertebras

On the post-mortem examination, an encapsulated nodule with $1 \mathrm{~cm}$ in diameter, filled with a whitish purulent exudate, was observed adjacent to the $\mathrm{C} 2-\mathrm{C} 3$ vertebras. The consistence was fresh cheese-like (Figure 1B) and the pus invaded $\mathrm{C} 2$ and $\mathrm{C} 3$ vertebras, that also presented osteolysis. The lungs presented congestion and oedema. There was an absence of food content in the stomach that contained mucus. The urinary bladder was distended with urine. No more gross lesions were detected.

An impression smear of the nodule was performed and gram-positive bacteria (rods) and neutrophils (some degenerated) were observed. Representative tissues specimens were collected for histologic examination (12). Histopathology of the vertebras was not possible due to the extensive osteolysis which caused fragmentation of the material. Other microscopic findings included parasitic interstitial pneumonia and multifocal hepatitis. The purulent material was also submitted to microbiological analysis. The agent Paeniclostridium sordellii was identified using VITEK $\AA$ system (ANC ID Car REF 21347, Biomérieux, France), after the grown in anaerobioses of small colonies with 1-4 $\mathrm{mm}$ in diameter that spread on the plate in a continuous firm, with a translucid coloration on the Blood BHI, for $24 \mathrm{~h}$ at $35-37^{\circ} \mathrm{C}$.

\section{Discussion and conclusion}

Although maxillary osteomyelitis had already been reported in E. europaeus (8), it is the first time that a cervical osteomyelitis is reported in this specie.

In this particular case, the diagnosis was only made during the post-mortem exam because it was not possible to perform any complementary diagnostic exams (e. g. radiography) before the animal die. After death has not possible to perform radiographic exams due to limitations on the resources.

The clinical signs that the animal presented could be associated not only to the deformation of the spine and compression of the spinal cord but also associated with the toxic effects of the bacteria. The port of entry for bacteria could have been a small skin wound that had already healed at the time of clinical presentation but 
was not possible to collect tissue of those areas to posterior histopathology exam. Since E.europeus have scavengers behaviours, live close to the ground and even in underground holes, and this pathogenic agent is common in soils, is possible that have invade a premortem wound leading to the development of the abscess. Local proliferation of the agent may had occurred, and the suppurate exudate formed may have extended by contiguity to the adjacent vertebrae. There are only a few reports of osteomyelitis in cervical vertebras in wild mammals (13), and this case report for the first time a cervical osteomyelitis in a wild $E$. europaeus.

In veterinary $P$. sordellii has an important role particular in farm animals, having been associated to gas gangrene in ruminants, pigs, and horses, ulcerative enteritis in quail, abomasitis in lambs, necrotic enteritis in chickens, omphalitis in foals, and other enteric infections in wild species (e.g. bears, pelicans) (9). But it is the first time that $P$. sordellii is associated to an osteomyelitis.

Reports as this are import not only to improve the knowledge on disease in that $E$. europaeus, but also in other domestic and non-domestic species, including humans, since this agent has the potential of becoming zoonotic.

\section{Acknowledgements}

We are grateful to Parque Biológico de Gaia, Laboratory of Histology and Anatomic Pathology of UTAD and INNO Veterinary Laboratory for the support in the execution of this work.

The author(s) declare that there are no conflicts of interest. This research did not receive any specific grant from funding agencies in the public, commercial, or not-for-profit sectors.

No ethical approval was obtained because this study did not involve a prospective evaluation and did not involve laboratory animals. Informed consent for publication of clinical information's and images was obtained from the Wildlife Rehabilitation Centre of Parque Biologico of Gaia and from the ICNF (Instituto da Conservação da Natureza e das Florestas).

\section{References}

1. Reeve N. Hedgehogs. London : Poyser, 2002: 304 p. 2. Mullineaux E, Best D, Cooper JE. BSAVA manual of wildlife casualties. Gloucester : British Small Animal Veterinary Association, 2003.

3. Pettett CE, Moorhouse TP, Johnson PJ, Macdonald DW. Factors affecting hedgehog (Erinaceus europaeus) attraction to rural villages in arable landscapes. Eur J Wildl Res 2017; 63(3): art. 54.

4. Rasmussen SL, Berg TB, Dabelsteen T, Jones OR. The ecology of suburban juvenile European hedgehogs (Erinaceus europaeus) in Denmark. Ecol Evol 2019; 9(23): 13174-87.

5. Bexton S. Hedgehogs. In: Mullineaux E, Keeble $\mathrm{E}$, eds. BSAVA manual of wildlife casualties. $2^{\text {nd }} \mathrm{ed}$. Gloucester : British Small Animal Veterinary Association, 2016: 117-37.

6. Martinez J, Rosique, Alejandro I, Royo M. Causes of admission and final dispositions of hedgehogs admitted to three Wildlife Rehabilitation Centers in eastern Spain. Hystrix 2014; 25(2): 107-10.

7. Maier K, Fischer D, Hartmann A, et al. Vertebral osteomyelitis and septic arthritis associated with Staphylococcus hyicus in a juvenile peregrine falcon (Falco peregrinus). J Avian Med Surg 2015; 29(3): 216-23.

8. Martínez LS, Juan-Sallés C, Cucchi-Stefanoni $\mathrm{K}$, Garner MM. Actinomyces naeslundii infection in an African hedgehog (Atelerix albiventris) with mandibular osteomyelitis and cellulitis. Vet Rec 2005; 157(15): 450-1.

9. Nyaoke AC, Navarro MA, Fresneda K, et al. Paeniclostridium (Clostridium) sordellii-associated enterocolitis in 7 horses. J Vet Diagn Invest 2020; 32(2): 239-45.

10. Rabi R, Turnbull L, Whitchurch C, Awad M, Lyras D. Structural characterization of Clostridium sordellii spores of diverse human, animal, and environmental origin and comparison to Clostridium difficile spores. mSphere. 2017; 2(5): e00343-17. doi: 10.1128/mSphere.00343-17

11. Sasi Jyothsna TS, Tushar L, Sasikala C, Ramana CV. Paraclostridium benzoelyticum gen. nov., sp. nov., isolated from marine sediment and reclassification of Clostridium bifermentans as Paraclostridium bifermentans comb. nov. Proposal of a new genus Paeniclostridium gen. nov. to accommodate Clostridium sord. Int J Syst Evol Microbiol 2016; 66(3): 1268-74.

12. Mescher AL. Junqueira's basic histology: text and atlas. 13th ed. New York : McGraw-Hill Education, 2013.

13. Raymond JT, White MR. Necropsy and histopathologic findings in 14 African hedgehogs (Atelerix albiventris): a retrospective study. J Zoo Wildl Med 1999; 30(2): 273-7. 


\title{
OSTEOMIELITIS VRATNIH VRETENC PRI PROSTOŽIVEČM EVROPSKEM JEŽU (Erinaceus europaeus), POVZROČEN Z BAKTERIJO Paeniclostridium sordellii
}

\author{
A. Garcês, V. Soeiro, S. Lóio, F. Silva, I. Pires
}

Izvleček: Prosto živeča odrasla samica evropskega ježa (Erinaceus europaeus) je bila sprejeta v Center za rehabilitacijo divjih živali Parque Biológico de Gaia (Portugalska) s hudo dihalno stisko in slabim telesnim stanjem. Njen vrat je bil premaknjen kavdalno za 60 stopinj. Med sekcijo po smrti so opazili absces na vratnih vretencih. Iz gnojnega eksudata lezije je bila izolirana bakteerija Paeniclostridium sordellii. V članku poročamo o prvem zabeleženem primeru osteomielitisa, povezanega s P. sordellii, na vratnih vretencih in o prvem primeru opisa tovrstne patologije pri evropskem ježu, povezani s tem povzročiteljem.

Ključne besede: Erinaceus europaeus; Portugalska; Paeniclostridium sordellii; osteomielitis 